\title{
Productive Protection and Tourism Development of Intangible Cultural Heritage Research on
}

\author{
Taking the Traditional Technology of Yongsheng Water Flaky Cake as an Example*
}

\author{
Jihong Li \\ College of Tourism and Culture of Yunnan University \\ Lijiang Tourism Research Center of Lijiang Teachers College \\ Lijiang, China 674199
}

\author{
Cheng Wang** \\ College of International Tourism and Business \\ Administration of Lijiang Teachers College \\ Lijiang Tourism Research Center of Lijiang Teachers \\ College \\ Lijiang, China 674199 \\ **Corresponding Author
}

\author{
Guifang Yang \\ Lijiang Development Research Center \\ Lijiang, China 674199
}

\begin{abstract}
The intangible cultural heritage of traditional technologies and arts is a living culture, so productive protection is an important means for its protection and inheritance. The making technique of water flaky cake in Lijiang Yongsheng is provincial intangible cultural heritage. It has been rooted in the fertile soil of Yongsheng traditional culture for nearly 100 years. It has been inherited and innovated in production and living practice, and has high historical and cultural value and potential tourism value. Its productive protection can be archived through the protection of intellectual property rights, vertical inheritance and transverse spread, and launch of new stuffs. It can elevate the reputation of water flaky cake, enhance the local characteristics of tourism, promote the local economic and social development, and realize the benign interaction between the protection of intangible cultural heritage and economic development through the combination of the forms of tourism commodity, spread of traditional culture and "tourism + industry".
\end{abstract}

Keywords-intangible cultural heritage; water flaky cake; productive protection; tourism development

\section{INTRODUCTION}

The intangible cultural heritage is different from the material cultural heritage and has the characteristics of "living rheological property". It is a kind of living culture with its own evolutionary law. It is constantly innovated and reformed in the interaction with its surrounding environment, and seeks the way of productive protection as far as possible without affecting its future development direction, and forms the

*Fund project: This paper is supported by the National Natural Science Foundation Project (41361037), the Major Consultation and Demonstration Project of Lijiang Development Research Center (Project Number: 2016LF01Z), and the School-level Scientific Research Project of College of Tourism and Culture of Yunnan University (Project Number: 2017XY14).

CLC No.: G122 Document code: A Article No.: benign interaction with tourism development [1]. We can transform the non-material cultural resources into the cultural industry resources which are deeply integrated with culture and tourism.

On June 2, 2017, the Yunnan Provincial Government announced the fourth batch of provincial non-material cultural heritage representative project list. The making technique of water flaky cake in Lijiang Yongsheng has been selected in the list of traditional skill. Water flaky cake is a traditional technique rooted in the fertile soil of Yongsheng traditional culture. It originated from the folk, developed in the folk and has been inherited by the folk. It remains and continues to today, owing to unfailing public praise, the tenacious spirit and strict family tradition of the inheritors. However, in the wave of modernization and commercialization, the traditional technology of water flaky cake has been challenged by modern technology. For example, Hand kneading is challenged by automatic dough kneading machine, and oven baking is challenged by baking machine. It is undoubted that the water flaky cake made by traditional technology has good taste and high historical and cultural value. But it is time-consuming and labor-consuming. The water flaky cake made by modern technology has poor taste but high production efficiency. When modern technology is dominant, the economic benefits are self-evident, while traditional technology is facing a dilemma. How do we choose between them? It depends not only on the adherence of the inheritors and the protection policy of intangible cultural heritage, but also on the values of consumers. At present, with the development of tourism in all parts of the country, the integration of primary, secondary and tertiary industries has become a major trend. Among the six elements of "eating, living, traveling, shopping and entertainment" tourism, the integration of "shopping" in water flaky cake is a natural process. It is also natural for some 
businessmen to use modern technology to produce a large number of water flaky cakes to meet the "shopping" demand of tourists. In the face of challenges, it is particularly important to study how the traditional techniques survive, how to effectively protect human historical and cultural genes, how to protect the production of water flaky cake and how to develop tourism. In recent years, the values of tourists have also undergone profound changes. Pursuing quality, safety and original flavor has become the new consumption demand of most consumers, which is very beneficial to the productive protection of intangible cultural heritage of traditional arts and crafts. However, this kind of protection is passive and only positive protection can make it survive, inherit and innovate.

\section{THE HistoricAl ORIGIN OF WATER FlAKY CAKE}

Water flaky cake is a kind of special cake made by traditional folk handicraft, which is popular in Yongsheng County. It has a long history and unique craftsmanship. The production place Yongsheng is rich in natural resources, and profound in cultural deposits. It was an important traffic fort and post on the ancient southern silk road and ancient teahorse road in history, and settlement place of President Mao Zedong's ancestors. The Biantun culture, represented by Taliu culture and Mao's culture, has a long history, and has very distinct regional characteristics [2].

Yongsheng is located in the northwest of Yunnan Province, which is subordinate to Lijiang. It is located in the upper reaches of the Yangtze River and the central of Lijiang. The county is 82 kilometers from the east to the west, 140 kilometers from the south and north, with a total area of 4950 square kilometers. It is adjacent to Huaping in the east, Ninglang in the north, ancient town and Dali Heqing across the Jinsha River in the west, and Dali Binchuan and Chuxiong Dayao in the south [3]. The topography is high in the northeast and low in the southwest, with the highest altitude of 3963.56 meters, the lowest altitude of 1056 meters, and the relative height difference of 2897.3 meters. It has obvious threedimensional climate characteristics. Complex and diverse topography, landforms and climatic environment result in the diversity of ecosystems and biodiversity in the territory. Due to the vast land, sufficient light and heat, it is especially rich in agricultural resources, abounding in rice, sugar cane, fluecured tobacco, peanuts, vegetables, mulberry, apples, longan, walnut and other agricultural products. It enjoys the reputation of "land of fish and rice" and "Granary of Northwest Yunnan", providing abundant and fine quality raw materials for the inheritance of water flaky cake making technique.

A large number of unearthed cultural relics show that as far as the Neolithic Age, Yongsheng this ancient land has been human reproduction. In the sixth year of Yuanding (111 B.C.), under the reign of Emperor Wudi of the Western Han Dynasty, Yongsheng was a country of Suijiu, belonging to Yuexi Prefecture. The capital city was located in Xichang City, Liangshan Prefecture, Sichuan Province, until the Eastern Han Dynasty. Three years after the founding of Shuhan (AD 225), Zhuge Liang made a south expedition to set up prefectures and counties. Suijiu County was changed and subordinated to Yunnan Prefecture, the capital of which is now Dali. In the Eastern Jin Dynasty, the name was Gufu County and it was still belonging to Yunnan Prefecture, until the Liang and Chen Dynasties. In the seventh year of Emperor Wude of Tang Dynasty (624), the government set up Mi Prefecture, subordinated to the government office of Yao Prefecture. In the eleventh year of Emperor Zhenyuan of Tang Dynasty (795), Nanzhao Regime had set Dan in the north, and later renamed Jiedan, successively belonging to Jianchuan and Tieqiao. From the second year of Emperor Tianfu Shi Jingtang of the late Jin Dynasty to the end of the Southern Song Dynasty (937-1277), set up Ji Town and Shanju Prefecture, belonging to Dali. The descendants of Gao Shengtai, a former king of Dali, had been in charge of this prefecture for generations, and lasted for more than 800 years.

From the early Yuan Dynasty to the fifteenth year of the Yuan Dynasty (1278), set Shi Prefecture (jurisdiction over today's Yongsheng and Huaping). To the seventeenth year of the Yuan Dynasty (1280), it was renamed Beisheng Prefecture, belonging to Xuanfu Department of Lijiang Road. The name of "Beisheng" came from a story of Kublai Khan who sent an army from Gansu in the north and divided his troops into three parts at Dadu River and marched through three ways to attack Dali. One part first occupied Yongsheng, and took the meaning of "coming from the north and wining victory first". Up to the twenty-fourth year of the Yuan Dynasty (1287), it was upgraded to Beisheng Office, having jurisdiction over Beisheng, Yongning, Langqu and Shunzhou, with Family Gao as magistrate, under the jurisdiction of Lijiang Road. In the fifteenth year of Emperor Hongwu of Ming Dynasty (1382), the army attacked Yunnan, Chiefs of local tribes Family Gao, Zhang and $\mathrm{Zi}$ surrendered to the Ming State. At first, it was still governed by Beisheng Office. In the seventeenth year of Emperor Hongwu of the Ming Dynasty (1384), Beisheng Office was changed to Beisheng Prefecture. Family Zhang was degraded as vice prefect of Beisheng Prefecture, Family Gao as magistrate of Beisheng, under the jurisdiction of Heqing Junmin Office. In the twenty-ninth year of Emperor Hongwu (1396), set Lancangwei Military and Civilian Department, and implemented "the policy of changing the tribe-leading system into official-appointing system". In the sixth year of the Ming Dynasty (1441), upgraded Beisheng as direct-controlled prefecture, subordinated to the Buzheng Administration of Yunnan Province. From then on it was not under the jurisdiction of Lancangwei Office. In the thirty-first year of Emperor Kangxi of the Qing Dynasty (1692), it was upgraded to Yongbei Office, and in the thirty-second year of Emperor Qianlong (1767), it was downgraded to direct-controlled Yongbei Hall. In 1913, it was further reduced to Yongbei County. In 1933, it was renamed Yongsheng and has been used to today [4].

Most of the Han people in Yongsheng came to this place because of Hongwu Deployment, many of them came from Hunan. It is understood that the ancestor of Zhou Yuhua, the inheritor of Yongsheng water flaky cake craftsmanship, learned from a master surnamed Pang. Master Pang's ancestral home was Hunan, and Zhou Yuhua's ancestor was also from Hunan.

Water flaky cake is named for its soft and delicious taste after being baked which is profiting from one process. The ready-made dough shall be placed in water and soaked for 
more than 3 hours. The inheritance of its production process is closely related to Family Yang on the Southwest Street of Yongbei Town, Yongsheng County. The recorded history of Yongsheng water flaky cake can be traced back to 1933 years ago. According to oral account of Zhou Yuhua, the inheritor of Yongsheng water flaky cake craftsmanship, his greatgrandmother, Yang Shi (who was born in 1876 or so according to the research of her decedents), followed Master Pang (Yongsheng, native of Hunan Province) to learn how to make flaky cakes. She passed this skill on to his grandfather, Yang Shuxuan (born in 1899), who founded the "Qingxiang Zhai" Cakes and Pastries Shop, and carried forward this technique. Later his mother Yang Fangtao (born in 1932) inherited the family business. It has been inherited for four generations to Zhou Yuhua. Qingxiang Zhai, founded by his grandfather, has been very famous at that time. To this day, Zhou Yuhua has kept a wooden printing plate of "Qingxiang Zhai" at that time "Fig. 1".

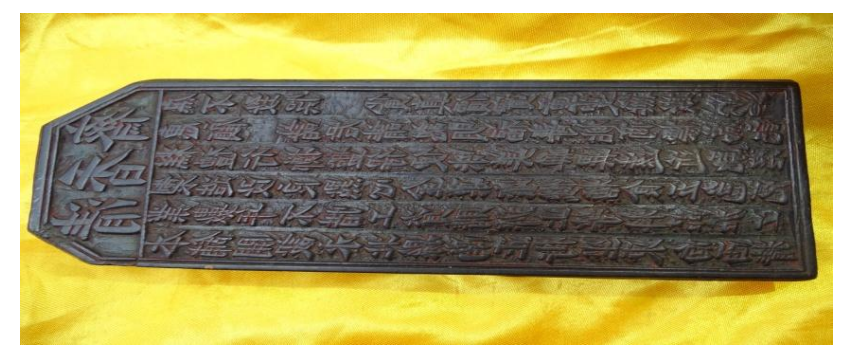

Fig. 1. "Qingxiang Zhai" Printing Plate (photo, provided by Yongsheng Cultural Center)

The contents of the printing plate are: "the shop opens at Nangzheng Street of Yongbei County and sits east and faces west. We have operated for years, and always select highquality materials of high prices as raw materials. We process, make and improve snacks, golden fruits, preserves, sweetmeats, five-colored rice cake, and so on. It is very continent to place them on plate to entertain guests. Our delicious and tasty products are famous for miles around. Please look for our mark Fushou peach, and never make a mistake. Our products are of high quality and fair price, and we always deal honestly with one's customers." A careful person will see that “味” on the plate misses half horizontal stroke on the right upper side. According to introduction of Zhou Yuhua, it was his grandfather's intention. His purpose is to remind future inheritors: ensure the quality of raw materials and products, so that the flavor will be authentic. Otherwise, one small error will make a great difference in flavor. Our ancestors used this traditional way to pass down the traditional culture and ancient skill. The craftsman spirit of pursuing honesty, perseverance and excellence is the spirit of the times that our society needs to carry forward.

From the content, the stereotype should be engraved between 1913 and 1932 (in 1913 Yongsheng was renamed Yongbei County, and to 1933 it was renamed Yongsheng again). According to it, the water flaky cake making technique of "Qingxiang Zhai" has been spread for at least more than 100 years in Yongsheng. Family Yang's "Qingxiang Zhai" has been awarded many times since its products are cheap and fine. The white water flaky cake made by Zhou Yuhua, the third- generation heir, was awarded as "Fine Ethnic Products" on August 29, 1985 by the National Affairs Committee of the Lijiang Regional Administration and the Urban and Rural Collective Enterprise Management Bureau in the First Session of Ethnic Special-needed High-quality Product Competition. In June, 2015, it was awarded as "Famous Desert of Yunnan" by the Yunnan Food and Beverage Association. In August 2015, it was awarded the Best Famous and Special Snacks Award at the first Yunnan Famous and Special Snacks and Ethnic Food and Culture Festival, and was also awarded the "Chinese Famous Desert" by the Chinese Cuisine Association.

On March 7, 1956, Yongsheng Handicraft Production Cooperative Union was established. Yang Shuxuan and his daughter were selected to work in the cooperative because of mastering the making technique of water flaky cake. Under the instruction of Yang Shuxuan and his daughter, most of the employees who worked in the handicraft production cooperative were good at making water flaky cake. At present, the mastery of water flaky cake making technique in Yongsheng is basically from the handicraft cooperative in the past. Nowadays, there are three or four water flaky cake factories in Yongsheng. In addition to the large-scale and perennial production of Zhou Yuhua's shops, other small-scale factories are mostly produced in their own homes only a few days before the Mid-Autumn Festival, and seldom make it, such as Wen Sibin's and Chen Jinzhen's. Zhou Yuhua was influenced in her childhood, carefully trained by her mother, and continually innovated after inheriting her ancestor's work. He introduces modern production techniques, enriches filling varieties, improves packaging, and expanding production. So far, Qingxiang Zhai has two branches in Yongsheng County, with more than 40 workers. Its products are exported to Beijing, Shanghai, Kunming and other places.

\section{The MAKING TECHNOLOGY OF WATER FLAKY CAKE}

The water flaky cakes are fragrant, sweet and crisp, not greasy and melt in the mouth, and have excellent taste. They are round in shape, with different specifications of large, medium and small size. There are many kinds of stuffs, such as sweet bean paste, ham, sugar, honey, and mixed nuts [5]. The technological process of water flaky cake can be found in Table 1 (according to the investigation report on the making technology of water flaky cake in Yongsheng County). 
TABLE I. TeChNological PRocess of WATER Flaky CAKE

\begin{tabular}{|c|c|c|}
\hline \multicolumn{2}{|c|}{ Technological Process } & \multirow{7}{*}{$\begin{array}{l}\text { 1. * Mince leaf fat and knead } \\
\text { dough with it and add no } \\
\text { water. A large amount of acid } \\
\text { substances can be detected in } \\
\text { leaf fat, which can produce a } \\
\text { large number of carbonyl } \\
\text { compounds, and help form } \\
\text { the characteristic flavor of } \\
\text { meat. At the same time, } \\
\text { furan compounds have been } \\
\text { detected in leaf fat, which are } \\
\text { the product of auto oxidation } \\
\text { of linoleic acid, and may be } \\
\text { an important aroma } \\
\text { substance in fat containing } \\
\text { food. These elements[6] have } \\
\text { not been detected in lard fat } \\
\text { oil. Choose raw leaf fat } \\
\text { instead of cooked lard oil, } \\
\text { which can reduce the } \\
\text { volatilization of these } \\
\text { substances which are the key } \\
\text { factors for the fragrance } \\
\text { overflow of flaky cakes. } \\
\text { 2. Soaking can make water, } \\
\text { oil and dough fully contact. } \\
\text { Cakes fully absorb water to } \\
\text { maintain a suitable humidity. } \\
\text { It keeps soft and flaky taste } \\
\text { after baking. }\end{array}$} \\
\hline $\begin{array}{l}\text { Selecting } \\
\text { materials }\end{array}$ & $\begin{array}{l}\text { Choose fine flour, good fresh } \\
\text { leaf fat and various flavors of } \\
\text { stuffs. }\end{array}$ & \\
\hline $\begin{array}{l}\text { Kneadin } \\
\text { g dough }\end{array}$ & $\begin{array}{l}\text { Mince the fresh leaf fat, mix } \\
\text { evenly with the flour, and } \\
\text { knead the dough vigorously } \\
\text { until it is even and soft. }\end{array}$ & \\
\hline $\begin{array}{l}\text { Making } \\
\text { cake }\end{array}$ & $\begin{array}{l}\text { Roll the dough into a round } \\
\text { strip with a diameter of about } \\
5.5 \text { centimeters, divide them } \\
\text { into small pieces, } 40 \mathrm{~g} \text { a } \\
\text { piece, and press them into } \\
\text { round wrappers and put the } \\
\text { stuffs about } 30 \mathrm{~g} \text { on the } \\
\text { wrappers and wrap the stuff } \\
\text { with wrapper and then press } \\
\text { them into round cake with a } \\
\text { diameter of about } 6-7 \\
\text { centimeters. }\end{array}$ & \\
\hline Soaking & $\begin{array}{l}\text { Soak the round cake into the } \\
\text { clear water for more than } 3 \\
\text { hours. }\end{array}$ & \\
\hline Baking & $\begin{array}{l}\text { 1. Baking under traditional } \\
\text { carbon fire: put the soaked } \\
\text { round cake onto a plate and } \\
\text { then a special furnace. Use } \\
\text { sealed carbon fire as primer } \\
\text { and add carbon fire to bake } \\
\text { for } 20 \text { minutes. } 2 \text {. Baking by } \\
\text { modern technology: place the } \\
\text { soaked round cake into the } \\
\text { baking pan, and then baked } \\
\text { in the oven for } 25 \text { minutes. }\end{array}$ & \\
\hline Package & $\begin{array}{l}\text { Usually use food packaging } \\
\text { paper with fine patterns. }\end{array}$ & \\
\hline
\end{tabular}

IV. The Production Protection Ways of WATER FLAKY CAKE

\section{A. Intellectual Property, the Core Element of Productive Protection}

On March 28, 2013, the Second Meeting of the Standing Committee of the 12th People's Congress of Yunnan Province adopted the Regulations on the Protection of Intangible Cultural Heritage of Yunnan Province, hereinafter referred to as the Regulations. Article 4 of the Regulations stipulates that the protection of intangible cultural heritage should pay attention to its authenticity, integrity and inheritance. The management, development, utilization and operation of intangible cultural heritage projects shall respect the form and connotation of intangible cultural heritage and prohibit the use of intangible cultural heritage in a distorting or derogating way [7]. Therefore, the making technology of water flaky cakes has been listed in the list of representative items of intangible cultural heritage at the provincial level of traditional craftsmanship, at the same time, it has been protected by intellectual property policy. The inheritor shall make full use of the exclusive rights enjoyed by him/her, safeguard his/her own legitimate rights and interests through illegally getting trademark rights and patent confirmation and other systems. If rights and interests are infringed, they may use the relevant provisions of intellectual property rights to protect the reputation of the inheritor and the enterprise, and stimulate the enthusiasm of the inheritor and the enterprise for inheritance and protection to achieve the protection of intellectual property rights of intangible cultural heritage of traditional arts and crafts.

\section{B. Vertical Inheritance and Transverse Spread, the Key Element of Productive Protection}

The vertical inheritance of intangible cultural heritage of traditional technology generally refers to family inheritance and mentoring inheritance. Intangible cultural heritage is an intangible cultural heritage, and the skills in the process of inheritance can be embodied in the inheritors. The intangible technologies are continued by passing them to their family and apprentices in a vertical way, so as to achieve productive production. It is not enough for this technique to be carried forward only by vertical inheritance from generation to generation. The inheritors are not only the holders but also the disseminators. They should enhance their influence through horizontal spread. They can call on more individuals and enterprises to pay attention to intangible cultural heritage, carry forward traditional culture and consciously enter the ranks of non-material cultural heritage protection. In order to ensure the authenticity and inheritance of the traditional craft products and realize the overall protection in the transverse spread, the alliance standard of the traditional craftsmanship of water flaky cakes should be formulated under the guidance of the quality and technical supervision department, and the enterprises should sign the alliance standard together, so as to standardize the production behavior of the water flaky cakes enterprises [8]. The establishment and implementation of alliance standards can not only avoid vicious competition, but also let the flaky cake making technology return to the tradition.

\section{Launch of New Stuffs, the Innovation Element of Productive Protection}

The core technology of the traditional technique of water flaky cake is to choose the best fresh leaf fat and to soak the round cake into the clear water for more than 3 hours. This process cannot be changed in productive protection, or it will lose its authenticity. And this intangible cultural heritage will disappear. However, the types of stuffs can be innovated and enriched with the changing times and people's needs. The different kinds of stuffs do not affect the core technology of water flaky cake, on the contrary, water flaky cake can be developed in the inheritance and become more perfect. In recent years, with the development of ecological industry, the variety of water flaky cake stuffs is more and more abundant, such as rose, red bean, chestnut, strawberry, pineapple, blueberry, golden orange, grape and so on, which is to meet the different tastes of consumers. The next step is to look farther. We can draw lessons from the old Chinese brand pie recipe, such as Beijing Poria Cocos Cake, or make health care products, such as red bean and coix rice filling cake, Chinese yam and jujube filling cake, purple potato and pumpkin filling cake, Lily and honey filling cake according to the principle of traditional Chinese medicine. 


\section{TOURISM DEVELOPMENT OF WATER FLAKY CAKE}

\section{A. To Meet the Needs of Tourists in the Form of Tourist} Commodity

In the practice of living inheritance and protection of intangible cultural heritage, the integration of tourism is the most effective way of productive protection. Different types of intangible cultural heritage have different forms of expression, and the development methods of tourism products are also different. The understanding of local conditions and customs, regional culture, local manufacturing and local brands is one of tourist's purposes for travel, and these contents can be displayed through tourism commodities. Tourism commodities are an important part of tourism. Choosing and purchasing tourism commodities with local characteristics in tourist attractions is a souvenir for tourists or a gift to relatives and friends. Developing tourism commodities and increasing the proportion of tourism shopping in tourism revenue can help transform "ticket economy" into "industrial economy" under the background of global tourism. As a provincial non-material cultural heritage of Yongsheng County, water flaky cake is a well-known delicacy for local residents. It can be developed into a tourist commodity to meet the needs of tourists for eating, and at the same time, it can also meet the tourists' needs of understanding regional culture, purchasing local brands, presenting relatives and friends, and can also avoided the homogenization of tourism commodities currently.

\section{B. To Enhance the Protection Awareness of People on Non- material Cultural Heritage by Means of the Spread of Traditional Culture}

The intangible cultural heritage is the most regional tourism resources, forming the unique cultural charm of the region. It is the crystallization of local residents' diligence and wisdom, but also the treasure of Chinese civilization. Tourism development is a way to protect it. However, some of the nonmaterial cultural heritage projects in Lijiang are in the state of active development and some are in the state of passive waiting. On the whole, the integration degree with tourism is not high. Yongsheng water flaky cake contains rich food culture and historical cultural connotation, and has potential tourism value. While satisfying the "eating" and "purchasing" desire of tourists, the cultural connotations of non-material cultural heritage are skillfully integrated into tourism commodities in the aspects of raw materials, inheritors, production tools, production techniques, packaging techniques, advertising and publicity of water flaky cake, so that tourists can feel the unique dietary culture, historical and cultural connotations of Yongsheng. It is conducive to giving full play to its powerful display function, propaganda function and educational function and highlighting the real value of tourism commodities, which can enhance the protection awareness of tourists on intangible cultural heritage.

\section{To Promote the Water Flaky Cake Selling to the Whole Country in the Form of "Tourism Plus Industry"}

"Tourism + industry" has brought huge added value to industry. With the progress of human material civilization and spiritual civilization, people's requirements for the quality of life are getting higher and higher. Green consumption has become a fashion trend. Developing green food vigorously is the most advantageous, characteristic and promising ecological industry in Yongsheng County. Food culture is an important part of non-material cultural heritage tourism experience. It integrates the theme of water flaky cake with green food and develops interactive industrial tourism products, such as visiting production lines and tourist experience areas, so that tourists can experience the production process of water flaky cake and the processing process of green food, and experience the wisdom of traditional techniques and the charm of modern technology. Through the development of the experiential tourism project of making water flaky cake, it can not only improve the pleasure of tourists' participation, but also create more employment opportunities for Yongsheng County, realize the coexistence pattern of old-fashioned handicraft workshops and industrialization, expand the form of transmission carriers, innovate the means of circulation, extend the industrial chain, and realize the integrations of cultural tourism resources management, cultural tourism product development, cultural tourism product promotion and cultural tourism service, and promote water flaky cake selling to the whole country. Even it may promote a new economic growth point in Yongsheng County.

\section{CONCLUSION}

From the two-way perspective of production protection and tourism development of intangible cultural heritage, taking the inheritance and development of water flaky cake making technique in Yongsheng County, Lijiang City as an example, this paper systematically combs the historical origin and production technology of water flaky cake in Yongsheng County of Lijiang City, and puts forward the productive protection ways of water flaky cake in Yongsheng County of Lijiang City. The three elements of the ways are the protection of intellectual property rights, vertical inheritance and transverse spread and launch of new stuffs to achieve productive protection. At the same time, the paper puts forward three forms of water flaky cake tourism development in Yongsheng County of Lijiang City: to promote the popularity of water flaky cake in the form of tourism commodity, spread of traditional culture and "tourism + industry", to enhance the local characteristics of tourism, promote the local economic and social development, and realize the benign interaction between the intangible cultural heritage and economic development. This paper does not select the same kind of cases for horizontal comparison. But in the future study the author will select a number of intangible cultural heritage cases for comparative study, and further summarize the relationship between the productive protection of intangible cultural heritage and tourism development.

\section{REFERENCES}

[1] Wang Wenzhang. Introduction to Intangible Cultural Heritage. Beijing: Culture and Art Press, 2006.

[2] Yongsheng Party Committee Propaganda Department. Ecological Plateau and Charm Yongsheng. Red Flag Manuscript, 2009 (2): 46.

[3] Yongsheng History Committee Office. Yongsheng Situation, 1999.

[4] Yunnan Yongsheng Chronicle Compilation Committee. Yongsheng Chronicle (1978-2005). Kunming: Yunnan People's Publishing House, 2014. 
[5] Li Shuyan. Investigation Report on the Production Techniques of Yongsheng Water Flaky Cake. Shanxi Youth, 2013 (22): 202.

[6] Xu Yongxia, Chen Qingchan \& Miu Wenhua. Comparison Study of Volatile Compounds from Lard Fat derived from Different Sources. Food Science, 2010 (8): 177-180.

[7] Yunnan Provincial People's Congress Standing Committee. Regulations on the Protection of Intangible Cultural Heritage of Yunnan Province. 2013.

[8] Lin Fengqun. Discussion on the Productive Protection of Intangible Cultural Heritage - Taking the Traditional Making Technology of Almond Cake in Juxiangyuan as an Example. Cultural Heritage, 2010 (1): 146-149+159-162. 